University of Nebraska - Lincoln

DigitalCommons@University of Nebraska - Lincoln

Journal of Women in Educational Leadership

Educational Administration, Department of

Summer 9-17-2021

\title{
'Let Us Roll Up Our Sleeves': Amplifying Female Academic Leadership Through Collaboration and Mentorship
}

Amy Poland

St. Joseph's College-New York, apoland@sjcny.edu

Jo Anne Durovich

St. Joseph's College-New York, jdurovich@sjcny.edu

Rachel Schwartz

St. Joseph's College-New York, rschwartz@sjcny.edu

Follow this and additional works at: https://digitalcommons.unl.edu/jwel

Part of the Educational Administration and Supervision Commons

Poland, Amy; Durovich, Jo Anne; and Schwartz, Rachel, "'Let Us Roll Up Our Sleeves': Amplifying Female Academic Leadership Through Collaboration and Mentorship" (2021). Journal of Women in Educational Leadership. 276.

https://digitalcommons.unl.edu/jwel/276

This Article is brought to you for free and open access by the Educational Administration, Department of at DigitalCommons@University of Nebraska - Lincoln. It has been accepted for inclusion in Journal of Women in Educational Leadership by an authorized administrator of DigitalCommons@University of Nebraska - Lincoln. 
Journal of Women in Educational Leadership, 2021 doi: 10.32873/unl.dc.jwel.200

http://digitalcommons.unl.edu/jwel/

ISSN 2379-2191

Journal of

Women in

Educational

Leadership

\title{
'Let Us Roll Up Our Sleeves': Amplifying Female Academic Leadership Through Collaboration and Mentorship
}

\author{
Amy Poland, Ph.D., Jo Anne Durovich, Ph.D., LMSW, \\ \& Rachel Schwartz, Ph.D.
}

St. Joseph's College-New York, 155 W. Roe Blvd., Patchogue, NY 11772

Tel: 631.687 .1209 (A.P.); 631.687 .5193 (J.A.D.); 631.687 .4578 (R.S.)

Email: apoland@sjcny.edu ; jdurovich@sjcny.edu ; rschwartz@sjcny.edu

\begin{abstract}
The strengths of female leadership are illustrated through the 400 year history of the Catholic Sisters of St. Joseph (CSSJ) and their commitment to their charism which focuses on unity, inclusion and relationship building. Within the colleges they established, the Sisters have demonstrated their commitment to collaboration in their many leadership positions - both formal and informal - within the academy. This article focuses on the leadership of the Sisters as demonstrable examples of female leadership within academia, and makes suggestions for carrying the charism of the CSSJ into the future, expanding their focus on inclusivity to incorporate a broad expanse of female leaders.
\end{abstract}

Keywords: female leadership, leadership, mentoring, collaboration 


\section{Introduction}

"Let us roll up our sleeves to do all of which women are capable as we have from the beginning," CSJ Charism Prayer, Joan Mitchell, CSJ (Malinsky, 2019, p 48)

An inclusive understanding of contemporary academic leadership must include a diversity of experiences. In particular, we must amplify women's voices so they can be included in the narrative of higher education leadership. Unfortunately, we have a much better sense of why women do not succeed in leadership roles in the academy than how they do (Bowles, 2012). Furthermore, the dominance of "masculine practices and leadership norms" has excluded women from leadership roles (Dunn, Gerlach and Hyle, 2014) as well as erasing women's experiences from our understanding of academic success. While collaboration has traditionally been seen as a feminine aspect of leadership, the recent COVID-19 pandemic has shown us the value of collaboration for all academic leaders as new relationships were formed across the institution in an effort to provide the best possible experience for students, faculty and staff.

In this paper, we explore how the charism of the Sisters of St. Joseph creates a unique environment in which women's voices are amplified through claiming space and collaborative leadership.St. Joseph's CollegeNew York (SJC) has a long history of commitment to the educational needs of women and to social justice more generally. From early in the College's history, female leadership was not only accepted, but also expected. This history lends itself easily to developing female leaders and can serve as a model for female leadership in other academic environments.

\section{"Weaving Inclusive Love" - The Charism of the Sisters of St. Joseph}

"Our story springs from a small group of courageous women. They were lace makers who wove a pattern of inclusive love across France and across our world." Weaving Inclusive Love Joanne Gallagher, CSJ (Malinsky, 2019, p 49) 
In the 1600 , a group of women came together in a small town in France to help their neighbors after the area was devastated by religious wars. These women, in Le Puy, France, dressed as widows, went out into the community and asked what others needed and then worked to provide those needs. The women, who became the Sisters of St. Joseph, lived out their faith by serving their neighbors rather than being cloistered away from the world. They believed the future of society depended on the education of women and wanted to empower individuals through education and opportunities for work. For example, they taught women in the community the skill of making lace so they were able to make a living without resorting to prostitution or other forms of exploitation. The needlework also provided an opportunity for establishing relationships with these young women and a context in which to establish confidence. It was this desire for intentional relationships that set these women apart from other religious groups at the time. They wanted to work for meaningful relationships among themselves, with the neighbor, of the neighbor with others and themselves and all with God, and this charism continues today (Cavenaugh, 2004; Malinsky, 2019).

The Sisters of St. Joseph are one of the first communities of sisters in the Catholic Church with a mission of active service to the community outside the walls of the cloister. When the Sisters of St. Joseph came to the United States, they established schools for a number of underserved communities: poor children, children of freed slaves, the deaf community, and eventually colleges and universities. The sisters established at least 28 colleges around the United States; in 1985, twelve colleges formed what is today the Association of Colleges of the Sisters of St. Joseph (ACSSJ). Nine colleges remain in the consortium today and are called to carry the legacy of the Sisters forward. The shared values of the ACSSJ colleges (Malinski, 2019: p.6), established in the United States between 1905 and 1928, include:

- Creating hospitable and caring campus communities

- Manifesting concern for all without distinction

- Addressing the needs of the times

- Striving for excellence in all endeavors

- Working to make a difference in the local and world community 
More than three and a half centuries later, the Sisters continue to weave the story of inclusive love throughout their communities, giving voice to those without one. The mission of the contemporary St. Joseph community is to be an agent, an active force, for bringing hearts together. The Sisters believe that whatever is possible for women to do, they will do it; it is also a reflection of their desire for intentional relationships with their neighbors (Cavenaugh, 2004).

Founded in 1916 by the Sisters of St. Joseph, the mission of St. Joseph's College is to provide a strong academic and value-oriented education at the undergraduate and graduate levels, rooted in a liberal arts tradition that supports provision for career preparation and enhancement. Rooted in the charism of the sisters to serve humanity and "to love god and neighbor without distinction", the Sisters of St. Joseph founded the College to provide women a chance to obtain a college education. St. Joseph's College provided education and career preparation for a predominantly immigrant population and today continues to live out it's missin by offering innovative educational programs and services that contribute to the local and global community, prepare students for careers in a changing work environment and foster female leadership within the faculty.

The mission of St. Joseph's College, established throughout generations of female leadership, is rooted in a commitment to community, social justice and a life well-lived. For over 100 years, the College has embodied the educational mission of its founders, the Sisters of St. Joseph, who adamantly believed that education can transform individuals and communities. A recent survey of the SJC community found that the college does live its mission. Unsurprisingly, an overwhelming majority of respondents said that the college supports education; they also felt that the college contributes to and serves the community and that both of these continued to be important for the college in its continued desire to both fulfill the Sisters charism and the college motto: Esse Non Videri, To be, not to seem.

\section{"Relationships that Empower Us" - Collaborative Leadership and Mentoring}

"Give us courage to build relationships that empower us, so 
together we bring unioning love to our world." S. Suzanne Franck, CSJ (Malinsky, 2019, p 25)

The charism of the sisters, and the ways in which this charism is incorporated into the academic life of the college provides both a history and a model for moving forward in empowering female academic leadership. One such example of female leadership is related to the ability of female leadership to collaborate and mentor within academia, as the Sisters have within their spheres of influence - including education - for 400 years. Collaboration as a female leader in academia involves working with others in an integrated and cooperative way. Mentorship affords women the opportunity to support other women in the academic leadership pipeline through the ability to increase accessibility of leadership opportunities and both formal and informal mentoring relationships. The authors have found that collaboration and mentoring instills a great deal of trust in our colleagues as leaders as well as encouraging rising female leaders to pursue opportunities to build and demonstrate their own skills.

Collaborative leadership embodies the charism of inclusivity that is woven through the history of the CSSJs (Congregation of the Sisters of St. Joseph) and has particular relevance to the development of female leaders. Collaborative leadership allows women to claim our space as leaders through the generation of both formal and informal resource networks, establishing new and innovative partnerships and creating opportunities for mentorship in previously unexplored arenas. Collaborative leadership also allows the academic leader to respond quickly to emergent needs because trust and respect are shared between parties as a result of reciprocal relationships.

The collaborative leadership model of the Sisters has created an environment where women faculty are empowered to learn from each other despite the distinctions in their formal training. The emphasis on interdisciplinary leadership has led to collaboration on developing new programs, as well as mentorship on navigating the internal curriculum approval process within a higher education setting and integrating new teaching modalities into existing programs. The ability to collaborate has allowed the authors to to be both the beneficiaries and providers of valuable mentoring relationships, to amplify our own work 
while simultaneously acknowledging the work of our colleagues through shared knowledge, vision and responsibility and to explore emerging opportunities to further the charisms and mission of the Sisters.

\section{Example from the Field: New Program Development}

The history of a female leadership style centered on a commitment to social justice, inclusivity and service learning is perhaps most clearly demonstrated in the college's multi-year effort to develop a graduate degree in Social Work. New program initiatives are only considered when they adhere to the mission, vision and charism of the institution and the Sisters of St. Joseph and these proposals must explicitly embody the history of the college, specifically with regard to the Sister's historic focus on service, education (of women) and community building. Just as the charism of the Sisters of St. Joseph has historically been guided by the focus on inclusivity, justice and caring for one's neighbors as we would care for ourselves, so too is the profession of social work. The Sisters of St. Joseph have lived their lives in service to others and to their communities and this commitment serves as the foundation of the mission of the new Social Work program.

Further, the Sisters' practice of inclusivity and collaborative leadership guided the lengthy internal process by which the institution determined that a graduate degree in Social Work would further the institution's goals. In addition to being informed by the Sister's history of collaborative leadership, the institution has a long standing practice of shared governance between Administration and Faculty. This system of shared governance further strengthens the focus on female leadership qualities, including shared decision making, mentoring and collaboration. As such, the proposed MSW program was developed by faculty and vetted by various levels of faculty committees and Administration throughout the development process. This initial phase of development occurred during a several year period. The proposal was initially reviewed by every Department Chairperson at the college before then being reviewed by the faculty led Curriculum Committee. Significant revisions were made to the proposal after each review to incorporate stakeholder feedback and resulted in significantly strengthening the program proposal. 
Notably, the proposed program was developed by a female junior faculty member, a practicing social worker, under the mentorship of several administrators, both male and female. Throughout the mentoring process, the faculty member was influenced by the history of the Sisters of St. Joseph as well as the importance of the charism to the mission of the institution. This fundamentally altered the faculty member's understanding of the institution and allowed her to more clearly identify the role of the new social work program within this history. Perhaps most importantly, this mentoring process by both male and female administrators encouraged the faculty member to consider the historic role of the Sisters as leaders within the institution and the many ways that female leadership is valued and encouraged at the institution.

\section{Example from the Field: Remote Learning (in the Time of COVID)}

Collaborative leadership efforts also allowed the college to respond rapidly to the unprecedented impact of the COVID-19 pandemic. Specifically, the director of online learning was able to rapidly work with a team of colleagues in information technology and faculty development to facilitate this transition to online learning during a pandemic. Notably, the director has further been able to "share the load" of the pandemic response by working collaboratively with others from within the administration, faculty, staff and students, all working toward the goal of making the transition to remote learning, teaching and working as easy as possible for all.

Our fully online courses are approximately one-fifth of the courses offered every semester; one in four of our full-time faculty members had taught an online course prior to the transition and about half of the students at the college had taken an online course prior to the transition to remote learning. To say that transitioning the entire institution to remote learning, teaching and working was daunting would be an understatement. However, the relationships and collaborations that had been built with faculty, administration, staff and students eased the transition for all. While it might seem counterintuitive that collaboration and involving others made the institution more nimble, it allowed for sharing of responsibility and work in a way that capitalized on each 
other's strengths and the existing relationships that had already been established.

The team tasked with assisting students, faculty and staff with the transition to remote learning, teaching and working was led by women leaders within the college. The vice president for information technology, the director of online learning, the director of technology education, and the instructional designer are all female leaders on campus with expertise in online learning and technology. The relationship even before the transition between these leaders was one of collaboration and inclusivity. Though they report to different areas of the college (technology and academics), there is an intentionality in including each other in decision making as well as collaborating on projects that help the college move forward. In addressing the needs of the college during the transition, it was determined that a site would be built with resources for students, faculty and staff. The site would be accompanied by a series of tech chats, some on specific topics, some open for questions; these chats were a further collaboration with faculty development and the faculty technology committee at the college. When surveyed near the end of the semester, all areas of the college provided praise for these collaborative efforts to support the work of the college. The collaborative efforts of the college and the females leading the efforts were acknowledged in one of the early articles about supporting students during the transition in the Chronicle of Higher Education (Supiano, 2020).

\section{"Push us to be bold and creative" - Leading into the Future}

"Push us to be bold and creative-ready to risk going off the beaten path; yet realistic at all times-never neglecting common sense." Prayer Using the Maxims (author unknown:

Malinsky, 2019, 51)

In this paper we have explored how the Sisters of St. Joseph created an environment that fosters the advancement of women in leadership by amplifying women's voices through collaborative leadership. Collaboration and relationship building is a strength of female leadership that should be celebrated and replicated in an effort to bring more women 
into the fold of academic leadership. The continued direction provided by the sisters in both formal and informal leadership positions is vital to the continued mission and vision of the college. The current faculty, staff, students and alumni are supportive of the mission of the sisters and most can provide examples of seeing the charism in action from the sisters we have known. With declining numbers of sisters both at the college and in general, the future members of the college community will benefit from continued efforts on the part of college administration and faculty leaders, including faculty development efforts, to share the charism of the Sisters. One example of this can be seen in the efforts to document and preserve, through video and library archives, the wisdom and charism of the past leadership of Sisters as well as the mission of the college.

One of the ways to ensure the continued advancement of women in leadership positions is the reinforcement of the charism of the Sisters through faculty development programs aimed at breaking the glass ceiling that suppresses so many potential female leaders. The barrier must be shattered by the institutions who maintain its pressure through upholding the norms and practices of out-of-date and out-of-touch masculine leadership styles. Moving forward into an uncertain future, it is imperative that academic leaders know more about the lived experiences of faculty in order to establish pathways for claim-making and collaborative leadership. First, communication - asking and listening will be paramount to ensure that academic leadership reflects the best interests of the faculty and the best practices of the institution. Additionally, the academy must push ourselves to fight for a future that is inclusive and we must address a plurality of diversity in academic leadership. We can do this by using an intersectional approach to think more broadly and address inequalities through supportive, mentoring leadership that includes, but is not limited to, race, sexuality, ability, religion, and social class.

Contemporary challenges resulting from the worldwide pandemic response have shed light on the barriers faced by so many in academia, especially women. The academy is now experiencing an opportunity to work to support all faculty as they juggle work, health and caregiving responsibilities in uncertain times. The CSSJs have provided a framework to guide us as we move forward into a more inclusive future. Just 
as the Sisters have responded to the needs of their communities for 400 years, so too must the academy incorporate diverse perspectives into our structure. Representation matters and leaders must be able to provide support for female faculty interested in pursuing leadership positions.

\section{References}

Allen, M. (2019). The charism in time of conflict. CSJ Concordia Newsletter. Retrieved from: https://csjmn.org/ministry-leadersarticles/ministry leaders articles.php

Brown, B. (2018). Dare to Lead: Brave Work. Tough Conversations. Whole Hearts. New York, NY: Random House.

Cavanaugh, C., SSJ. (2004). Connecting CSSJ charism and mission with Catholic social teaching. National Meeting of the Association of Colleges of the Association of Colleges of Sisters of St. Joseph. Retrieved from: http://www.acssj.org/articles-papers.html

Dunn, D., Gerlach, J.M., \& Hyle, A.E. (2014). Gender and leadership: Reflections of women in higher education administration. International Journal of Leadership and Change: 2 (1), Article 2. Available at: http:// digitalcommons.wku.edu/ijlc/vol2/iss1/2

Gardner, L. (2019). What Happens When Women Run Colleges? https:// www.chronicle.com/interactives/20190630-womenincharge

Goffee, R. \& Jones, G. (2019). Why Should Anyone Be Led by You? What It Takes to Be an Authentic Leader. Boston, MA: Harvard Business Review Press

Hannum, K., Muhly, S., Shockley-Zalabak, P., \& White, J.S. (2014). Stories from the Summit Trail: Leadership Journeys of Senior Women in Higher Education. Denver, CO: Higher Education Resource Services (HERS). Retrieved from: http://hersnet.org/wp-content/uploads/2014/o7/ StoriesfromtheSummitTrail.pdf

Johnson, H.L. (2017). Pipelines, Pathways, and Institutional Leadership: An Update on the Status of Women in Higher Education. Washington, DC: American Council on Education.

Malinski, M. (Editor). (2019). That All May Be One. Indianapolis: Association of Colleges of Sisters of St. Joseph.

Miller, K., SSJ. (1995). The Sisters of St. Joseph college consortium: 
Mission and image. Occasional Papers on Catholic High Education, 1,114. Retrieved from: http://www.acssj.org/articles-papers.html

Murphy, R.P. (2016). Love, laundry and living the mission as an associate. Global Sisters Report: A Project of National Catholic Reporter.

Retrieved from https://www.globalsistersreport.org/column/trends/ love-laundry-and-living-mission-associate-40506

Sanaghan, P. (2019). Finding the Leaders We Don't Know

We Have. https://www.academicimpressions.com/blog/

finding-leaders-higher-education/

Sanaghan, P. \& Sidle, C. (2019). 6 Powerful Ideas for Building a First-Class Team on Campus. Denver: Academic Impressions.

Retrieved from: https://www.academicimpressions.com/ courses/0519-first-class-team-sfwd/

Supiano, B. (2020). How to help students keep learning through a disruption. Chronicle of Higher Education Teaching Newsletter. Retrieved from: https://www.chronicle.com/newsletter/ teaching/2020-03-19

$$
\neq \neq \neq \neq \neq
$$

\section{Author Bios:}

Amy Poland, Ph.D.

St. Joseph's College-New York

155 W. Roe Blvd.

Patchogue, NY 11772

apoland@sjcny.edu

Amy L. Poland, Ph.D. is an associate professor of Criminal Justice and the associate dean and director of online learning at St. Joseph's College in Patchogue, New York. She has previously authored or co-authored multiple publications including articles on the evaluation of online teaching, gender and perceptions of formal and informal systems of justice in Afghanistan, book chapters on the role of women in the war on drugs and serial rape and a report for the State of Nebraska on the need for and availability of mental health services for juvenile offenders. 
Jo Anne Durovich, Ph.D.

St. Joseph's College-New York

155 W. Roe Blvd.

Patchogue, NY 11772

jdurovich@sjcny.edu

Jo Anne Durovich,Ph.D. is a social worker and Associate Professor and Department Chair and Director of Human Services and Human Services Leadership programs at St. Joseph's College in Patchogue, New York. Dr. Durovich's professional interests focus on poverty and homelessness, program development in academic and non-profit settings, program evaluation, leadership and program innovation with a specific focus on increasing access to services for underserved students. She has previously authored or coauthored multiple publications including articles on the evaluation of online teaching, fair and affordable housing and health outcomes related to affordable housing.

Rachel Schwartz, Ph.D.

St. Joseph's College-New York

155 W. Roe Blvd.

Patchogue, NY 11772

rschwartz@sjcny.edu

Rachel Schwartz, Ph.D. is an Associate Professor of Sociology and Coordinator of the Human Relations Program at St. Joseph's College in Patchogue, New York. Her research has examined low-wage customer service work and consumer mis-information in the global food system. Dr. Schwartz's current research explores the particular challenges faced by women working in the corporate arena - from cubicle to C-Suite. She lives in Brooklyn, NY with her family. 